\title{
Floral biology and physicochemical characterization of wild passion fruit Passiflora setacea d.C BRS Pérola do Cerrado cultivated in the state of Rio de Janeiro
}

\author{
Ivan Marcos Rangel Junior ${ }^{1}$, Marco Antonio da Silva Vasconcellos ${ }^{2}$, \\ Raul Castro Carriello Rosa ${ }^{3}$, Fabio Ferreira Cruvinel ${ }^{4}$
}

\begin{abstract}
This work aimed to evaluate the floral and physicochemical characteristics of passion fruits BRS Pérola do Cerrado cultivar (Passiflora setacea D.C.), as well as its relationship with local climatic factors. Peak flowering, time in days of floral appearance until anthesis and until fruits harvest, floral morphometry, time of flower opening and closing, occurrence of natural self-pollination, geitonogamy and floral incompatibility, physicochemical characteristics of fruits and relationship with climatic variables were evaluated. Under the conditions of this study, it was observed that the flowering peak occurred in November and the time of flower opening ranged from 7:21 pm to 8:40 pm throughout the year, probably influenced by daily solar radiation; while the time of flower closing occurred between 6:00 am and 8:00 $\mathrm{pm}$. After closing, flowers showed no recurrence of floral opening. Flowers of Passiflora setacea species BRS Pérola do Cerrado cultivar are self-incompatible and do not allow geitonogamy. Therefore, for fruit formation, cross-pollination is necessary. Regarding fruit setting in the different pollination methods, rates were $34.6 \%$ when artificially made and $53.5 \%$ in case of natural pollination. Fruits had, on average, longitudinal diameter of $4.9 \mathrm{~cm}$, cross-sectional diameter of $46 \mathrm{~mm}$ and fresh mass of $55 \mathrm{~g}$, juice volume of $15.7 \mathrm{ml}$ per fruit, $13.31^{\circ}$ Brix and total titratable acidity of $1.7 \mathrm{~g} / 100 \mathrm{~g}$ ac. citric.
\end{abstract}

Index terms: climate, Passiflora, pérola do cerrado.

\section{Biologia floral e caracterização físico-química de frutos do maracujazeiro silvestre Passiflora setacea d.C cv. BRS Pérola do Cerrado cultivado no estado do Rio de Janeiro}

Corresponding author: juniorrangel2@hotmail.com

Received: April 13, 2018 Accepted: September 05, 2018

Copyright: All the contents of this journal, except where otherwise noted, is licensed under a Creative Commons Attribution License.

\section{(cc) $\mathbf{E} \mathrm{Y}$}

Resumo - O objetivo deste trabalho foi avaliar as características florais e físico-químicas do fruto de plantas da cultivar BRS Pérola do Cerrado de maracujazeiro silvestre (Passiflora setacea D.C.), bem como sua relação com os fatores climáticos locais. Foram avaliados o pico de florescimento; o tempo em dias do aparecimento floral até à antese e, em seguida, até à colheita dos frutos; a morfometria floral; os horários de abertura e de fechamento das flores; a ocorrência de autopolinização natural; de geitonogamia e de incompatibilidade floral; a característica físico-química dos frutos e a relação com as variáveis climáticas. Nas condições deste estudo, foi observado que o pico de florescimento ocorreu no mês de novembro e que o horário de abertura das flores variou de 19 horas e 21 minutos a 20 horas e 40 minutos ao longo do ano, provavelmente influenciado pela radiação solar diária; enquanto o horário de fechamento das flores ocorreu entre 6 e 8 horas. As flores, após seu fechamento, não apresentaram recorrência de abertura floral. As flores da espécie Passiflora setacea cv. BRS Pérola do Cerrado são autoincompatíveis e não possibilitam a geitonogamia, e confirma-se, portanto, para que haja formação de frutos, a necessidade de polinização cruzada. Quanto ao pegamento de frutos nos diferentes métodos de polinização, as taxas foram de 34,6\% quando foram feitas de forma artificial e de 53,5\% quando houve polinização natural. Os frutos apresentaram, em média, diâmetro longitudinal de 4,9 cm, diâmetro transversal de 4,6 cm e massa fresca de $55 \mathrm{~g}$, volume de suco de $15,7 \mathrm{~mL}$ por fruto, $13,31^{\circ}$ Brix e acidez total titulável de 1,7 g/100g ác. cítrico.

Termos de indexação: clima, Passiflora, pérola do cerrado. 


\section{Introduction}

In Brazil, passion fruit cultivation has been reported from the earliest indigenous tribes to the present day. With a rich diversity of species and varieties, the botanical genus Passiflora is spontaneously present throughout Tropical America with indicators pointing to the existence of more than 500 species and Brazil is one of the main centers of origin of the genus, of 150 species of which 70 present fruits with industrial value and for fresh consumption and many of them with importance in the national and international markets (FALEIRO et al., 2005; FALEIRO et al., 2017).

The Passiflora setacea species was first observed in 1828 and its name, in Latin, makes reference to its arrow-shaped stipules. It is a Brazilian wild species commonly known as maracujá-do-sono, maracujádo-cerrado, among other popular names (FALEIRO et al., 2005), which presents important and desirable characteristics to the consumer market, since, in addition to its resistance to phytopathogens, the species has physical, chemical and sensory properties very appreciated by both fresh consumption and pharmaceutical and cosmetic industries (CAMPOS, 2010).

According to Endress (2001), the flower is the most complex morphological structure of plants because they are composed of a diversity of organs in an orderly pattern, which complexity makes them aesthetically attractive.

The emergence of the flower along the evolutionary scale of plants in the Earth's environment, precisely in the Cretaceous period, caused a real revolution in the plant kingdom, since from then on, ovules and seeds were protected in ovaries and fruits resulting from the folding and welding of carpels and no longer exposed to the environment, where the fixation of this structure was crucial for the exit of the aquatic environment and the conquest of the terrestrial environment and its dominion, thus originating Angiosperms. As all modifications require adaptation, new demands emerged with the lack of mobility of plants, requiring varied adaptations aimed at the attraction of pollinating animals or even to develop mechanisms for the dispersion of pollen by abiotic factors (GONÇALVES and LORENZI, 2011).

Floral biology involves flower-pollinator interaction, with beetles probably being the first pollinators, among other factors. However, it is believed that insects, birds and bats and other animals were the main cross-pollination agents. Originally, pollinators were attracted by pollen, but the energy expenditure of this dual function was high for plants and there was need to produce food that demanded less energy, originating the structures specialized in producing nectar as an alternative (TAKHTAJAN, 1980).
Passiflora setacea species presents floral characteristics that attribute to the bat the role of effective pollinator of the species (chiropteraphilia). The first report of chiropteraphilia in the genus Passiflora occurred in $P$. mucronata species, being reported later in $P$. ovalis and $P$. penduliflora. Some common characteristics were also observed among species pollinated by bat like nocturnal white flowers and androecium with anthers positioned in a single direction of the flower, which allows the access of bats to flowers, increasing the pollination efficiency. Another point that justifies chiropteraphilia in Passiflora setacea is the floral aroma, and Trans- $\beta$-Ocimene, a monoterpene compound responsible for the formation of sweet and fruity odors, and benzene aromatic compounds, present in great amounts in the flowers of this species, are characteristic of plants with nocturnal flowers and constitute a class of 113 volatiles attractive to several pollinators (ROCHA, 2015).

Wild passion fruit BRS Pérola do Cerrado cultivar was launched in 2013 by Embrapa Cerrados company, Federal District, after years of research and selection of wild accessions of the species and since then, it has been gaining space among producers in Brazil due to its desirable characteristics for fresh consumption and industrial, ornamental and functional processing. In addition, passion fruit BRS Pérola do Cerrado cultivar was obtained by polycrossing of selected plants, being the first cultivar of the species registered and protected with MAPA (EMBRAPA, 2013). (NOTE: There are no official production data for the state of Rio de Janeiro).

In this work, the aim was to increase the knowledge regarding the floral biology of Passiflora setacea BRS Pérola do Cerrado cultivar, considering its commercialization potential, as well as the development of the cultivar regarding climatic variables in the State of Rio de Janeiro.

\section{Material and methods}

This work was developed in the experimental field of Embrapa Agrobiologia, located in the municipality of Seropédica, metropolitan region of the state of Rio de Janeiro, from January 2017 to December 2017. The region has average elevation of 35 meters a.s.1. $\left(22^{\circ} 45^{\prime} 18.4\right.$ "S and $43^{\circ} 40^{\prime} 04.0^{\prime} \mathrm{W}$ ), marked with rainy and hot periods from October to March and transition period with irregular rains and mild temperatures between April and September, with annual average rainfall of $1200 \mathrm{~mm}$ and average temperature of $24.5^{\circ} \mathrm{C}$. According to Köppen's classification the region is characterized as Aw.

Climatic data used in this work were obtained from meteorological station (Ecologia Agrícola-A601) located at Fazendinha Agroecológica Km 47.

Twelve plants of $P$. setacea species BRS Pérola do Cerrado cultivar were used. This cultivar was obtained 
through conventional breeding and was launched by Embrapa in 2013 (EMBRAPA, 2018) and since then, it has been gaining the interest of several producers and consumers in different regions of Brazil, including in the state of Rio de Janeiro.

Plants were conducted in a trellis system at 1.8 meter high, spaced 3 meters between plants and 3 meters between rows. The soil of the area is characterized as RedYellow Argisol. Organic fertilization was carried out with manure every 2 months and synthetic mineral fertilizers were not used during this study. Weed management was performed with costal brush cutter, as well as the crowning of plants within a radius of $60 \mathrm{~cm}$ from the stem. Due to the absence of significant damage caused by pests and diseases, characteristics of the BRS Pérola do Cerrado cultivar, preventive measures were not adopted.

During the study period, four monthly visits were made to the experimental field to observe the presence of flowers throughout the year, obtaining the average number of open flowers for each month, later related to the climatic variables characteristic of the region, obtained from the local meteorological station.

To determine the time elapsed between the appearance of the floral bud until anthesis, 30 floral buds among 12 plants were randomly selected and identified with colored ribbons, with size of approximately $0.5 \mathrm{~cm}$ in length of growing branches.

The determination of the time of flower opening and closing was performed in periodic visits to the experimental field of Embrapa Agrobiologia, where the exact moments in which the anthesis and the closure of flowers were observed, and the flower was only considered totally open when petals and sepals were definitively positioned, ceasing the opening movement, presenting approximate angulation of $60^{\circ}$ in relation to the base of the flower. Flower closure was observed every 15 minutes until flowers were completely closed. The same flowers were observed on the next day to determine the floral opening recurrence.

At the moment of floral opening, the occurrence of different floral types was observed, defined by the evaluation of the curvature of styli in relation to the axis of anthers.

For the floral morphometry analysis, after the complete opening of flowers, 30 random flowers were collected from the 12 plants and, with the aid of a digital caliper and a scaler, length measurements were made between the ends of petals and sepals, flower diameter, androgynophore length and corolla and operculum distance at the level of the axis of anthers.

The determination of the time between anthesis and harvest was performed throughout the year, with colored ribbons, 28 naturally pollinated flowers (open pollination) and 26 manually pollinated flowers and the number of days from anthesis to harvest was observed, which in this species occurs with the natural detachment of the fruit from the plant.

Two different procedures were performed to analyze the floral self-incompatibility. In the first one, 20 pre-anthesis floral buds, characterized by floral expansion, were bagged with paper bag to observe if only with flower opening, it was able to self-pollinate and consequently fruit setting, being removed from the paper bag after seven days. In the second case, 20 floral buds in pre-anthesis were bagged and after flower opening, manual pollinations were carried out on each flower using a cotton-tipped stem to collect pollen, being distributed through the surface of the flower's stigmas, then, flowers were bagged again for seven days when to observe fruit setting.

In the auto-incompatibility among flowers of the same plant, or geitonogamy, flowers were bagged with paper bag and 20 flower buds in pre-anthesis were identified, and after full opening, flowers were crossed with each other using cotton-tipped stems and then bagged again.

In determining the compatibility among flowers of different plants, 30 flower buds in pre-anthesis were bagged, now from different plants, and with the aid of cotton-tipped stems, cross-pollinations were performed among plants using the pollen from the flower of a plant and depositing under the surface of the stigma of other flowers of different plants, and after this procedure, flowers were bagged again to avoid the presence of pollinating agents.

The physicochemical characterization of fruits was carried out with the random harvest of 24 fruits, which were used for physicochemical analyses. In the determination of metric variables such as cross-sectional, longitudinal, bark and ovarian cavity diameters, a digital caliper was used. For variable bark hardness, test was performed with the aid of a penetrometer with tip area equal to 8 $\mathrm{mm}$. Fruit weight was determined by weighing fruits in a digital analytical scale and the juice volume was evaluated using a graduated $50 \mathrm{~mL}$ beaker. In order to determine the chemical characteristics of fruits, refractometer was used to obtain soluble solids and for total titratable acidity, 5.0 $\mathrm{mL}$ of juice of each fruit in duplicate was used, added of $50 \mathrm{~mL}$ of distilled water and 2 drops of phenolphthalein indicator and titration was carried out with $0.1 \mathrm{~N} \mathrm{NaOH}$ until the color was turned to pink tone and the spent $\mathrm{NaOH}$ volume was checked and calculations performed.

Since it is a behavioral observation study and there are no hypotheses to be compared by means of treatments, descriptive statistics was used in the presentation and analysis of data obtained.

Table 1 shows the local climatic data for the period in which this study was carried out. 


\section{Results and discussion}

The flowering period of wild $P$. setacea $\mathrm{cv}$. passion fruit BRS Pérola do Cerrado cultivar during the year suffered a great variation (Table 2). It was observed that the highest average number of flowers occurred in November, followed by the month of December. From April to July, plants did not bloom and their vegetative growth remained stagnant without the presence of new branches and leaves. Vegetative growth resumed in the second half of June, when branches began to grow vigorously.

Benevide (2006) observed that Passiflora setacea species cultivated in the northern part of the state of Rio de Janeiro only flowered from October to March, presenting zero flow rate in the other months of the year.

However, Ataíde et al (2012) observed that when cultivated in Jaboticabal, state of São Paulo, the species showed flowering during all months of the year. The same was verified by Guimarães et al (2013) in plants cultivated in the Federal District, where BRS Pérola do Cerrado cultivar did not present off-season production.

It was observed that from the month of September, plants presented practically stable vegetative growth, verifying greater number of flowers in plants in the month of November, with an average of 33 flowers per day, considering the 12 plants. The number of flowers throughout the year was influenced by the photoperiod, and high correlation between number of flowers per month and this variable was observed $(r=0.809)$. In the months when plants did not show presence of reproductive organs (April to June), photoperiod was less than 11 hours and 30 minutes

Table 2 shows the mean number of monthly flowers for the study period and the mean length of days for Seropédica (RJ), where correlation of $r=0.541$ for mean temperature, $r=0.551$ for mean rainfall and $r=0.551$ for solar radiation with the number of flowers monthly evaluated, showing a tendency to increase the number of flowers with increasing number of climatic variables such as temperature, rainfall and average radiation (not significant for 12 data, Pearson correlation critical values $\mathrm{r}>0.57$ or $\mathrm{r}<-0.57,5 \%$ ).

The time elapsed between the appearance of the flower bud to flower anthesis varied from 13 to 14 days, with no correlation between this event and climatic variables, indicating that this episode is possibly governed by physiological or genetic characteristics. However, further clarification is required regarding this mechanism in Passiflora setacea species in order to elucidate which factors influence its floral induction.

The process of flower opening in wild Passiflora setacea was characterized by the expansion of the floral bud caused by the pressure exerted by stigmas and anthers on walls formed by the arrangement of petals and sepals, the latter welded together, which makes flower opening in a smooth way difficult, so opening occurs instantaneously. However, after this abrupt opening phenomenon, petals and sepals continue in a gradual descending movement of approximately 40 minutes until reaching curvature of approximately $60^{\circ}$ to the crown, at which time flowers were considered completely open.

During the year, there was variation regarding the time of flower opening, which occurred predominantly after 7:00 p.m., and flowers opening up to two hours after the first flower are also observed.

In January, flowers started the opening process at 9:00 p.m., in February and October the opening hours were around 8:30 p.m. and at 8:40 p.m., respectively. In November, the time dropped to 7:21 p.m.; therefore, P. setacea BRS Pérola do Cerrado flowers under the environmental conditions of the study site opened after 7:00 p.m.

Junqueira et al. (2005) observed that the anthesis of Passiflora setacea flowers, when cultivated under the environmental conditions of the Federal District, also opened after 7:00 p.m.; however, different times have been reported in different localities, strengthening the idea that the species presents different responses according to the climatic characteristics of the place of cultivation.

This variation was observed even in places within the same state, for example, in the state of Bahia, where in the municipality of Vitória da Conquista, anthesis occurred at 5:30 p.m., while in Cruz das Almas, opening occurred one hour later (RIBEIRO, 2014; JUNGHANS et al., 2015).

In the municipality of Jaboticabal, state of São Paulo, the anthesis of Passiflora setacea cultivated under local conditions occurred from 5:30 p.m. (ATAÍDE et al., 2012).

Passiflora setacea cv. BRS Pérola do Cerrado cultivar, under the local conditions of this study, showed well defined opening times when compared to the different days of the same month, varying little or almost nothing in relation to this event, with small variations throughout the year.

This variation in the time of opening of Passiflora setacea flowers was strongly influenced by daily solar radiation, which was explained by the high and negative correlation between this event and the climatic variable $(r=-0.9629)$.

Different from the variation observed for the flower opening time throughout the year, the time when flowers started the closing process showed no variation, with the same time being observed throughout the year for this phenomenon.

In a slow and gradual movement, flowers begin to close at approximately 6:00 a.m. in a process of up to two and a half hours until their full closure at 8:30 p.m., when petals and sepals in ascending movement returned the initial position and only stigmas remained on the outside 
of the flower. After flower closing, no opening recurrence was observed in the later days. In flowers that for various reasons there was no fruit setting, the green coloring lost tone throughout the days, becoming brown in a process characteristic of senescence tissues; finally, flowers dried completely and fell off from the plant.

Unlike yellow passion fruit (Passiflora edulis Sims f. flavicarpa) and sweet passion fruit (Passiflora alata Curtis), in which flowers of different types of curvature of styli were reported (RUGGIERO, 1987; VASCONCELLOS, 1991), Passiflora setacea flowers did not show definite curvature of the styli with respect to the axis of anthers, remaining in the initial position until the moment when flowers close.

With the force exerted by petals and sepals at the time of flower closing, styli assume elongated vertical standing positioning and stigmas appear on the outside of the flower, which does not allow classification and occurrence of the different types of curvature observed in yellow and sweet passion fruit.

Table 3 shows the mean values, mode and the standard deviation for the metric variables of flowers.

In the morphometry study, the Passiflora setacea flowers, under the conditions of this study, presented average diameter values of $7.9 \mathrm{~cm}$, being composed of five petals and five sepals.

Petals had white color on both sides with green rectilinear central vein from the base to the apex. The observed average length was $3.3 \mathrm{~cm}$, with petals of 3.2 $\mathrm{cm}$ being more frequently observed. Sepals presented the abaxial face of green color, characteristic of the floral bud, with prominent central nervure, while the adaxial face was white. Its average length was $3.4 \mathrm{~cm}$ with mode of 3.5 $\mathrm{cm}$. Bracts, in three units, are positioned at the insertion between the peduncle and the pedicel, which observed average length was 7.9 and $1.8 \mathrm{~cm}$, respectively. Corona has a single series of white filaments.

Androgynophoreo, which is the continuation of the peduncle and aims to raise the sexual organs of flowers, presented average length $3.2 \mathrm{~cm}$ and mode equal to $3.4 \mathrm{~cm}$. Ovaries had diameter of $3.7 \mathrm{~mm}$ and length of $5.6 \mathrm{~mm}$.

The results of the present study are partially in agreement with the characteristics described by Cervi (1997), where Passiflora setacea flowers present peduncle of eight to ten centimeters, three bracts located approximately one centimeter from the base of the flower, diameter of up to ten centimeters, sepals of 3.5 to 4 centimeters with green margin and center of white color. Petals are usually smaller than sepals and white. Corona filaments have about one centimeter in a single series. These differences with respect to the species description made by Cervi (1997) are due to the genetic variability within the species. In addition to these morphological characteristics, BRS Pérola do Cerrado cultivar presents desirable agronomic characteristics such as high productivity, greater resistance to pests and diseases and better physical and chemical characteristics of fruits, which were used in the selection and recombination work carried out in the breeding program of $P$. setacea species (EMBRAPA, 2018).

The distance between the axis of anthers to the corolla was $1.7 \mathrm{~cm}$, while the distance to the operculum was $2.9 \mathrm{~cm}$. For efficient flower pollination, the agent that disperses the pollen should be large enough so that when visiting the flower in search for nectar, its dorsal part is able to come into contact with the reproductive organs. Thus, the distance between the axis of anthers in relation to the corolla and the operculum will determine the best pollinator, which is usually the bat for Passiflora setacea species.

While styli did not present some logic as to the curvature, fillets were positioned in a single direction so that all anthers had a single orientation.

Rocha (2015) reported that the affinity between a plant species and its pollinator occurs through a set of factors. In plants where chiropteraphilia (bat pollination) is predominant, such as white flowers, unidirectional stamens, anthesis time and aroma are preponderant.

Gonçalves and Lorenzi (2011) reported that due to the fact that bats are robust animals, nocturnal and not sensitive to color variation, plant species pollinated by them tend to present flowers with long peduncles that project them out of the canopy due to their difficulty in making maneuvers and to the fact that they hold with the feet, in addition to the presence of white to green flowers and strong aroma.

The time between anthesis and fruit harvest was 39 to 40 days. Of the 26 flowers artificially and cross pollinated (between plants), only 9 presented fruit setting, representing a rate of $34.6 \%$ for this study. In the natural or open pollination of the 28 flowers exposed to the pollinator agent, 15 presented fruit setting, presenting $53.5 \%$ success in fruit setting by this method, where the average time to harvest did not vary between methods, being from 39 to 41 days.

Table 4 shows the fruiting rate for each pollination method.

Ataide et al. (2012) reported that in the conditions of Jaboticabal (SP), the time of Passiflora setacea harvest ranged from 36 to 50 days, corroborating this study; however, differing in the fruit setting rates, where the authors observed rate of $3.3 \%$ when in natural pollination and $63.6 \%$ when in artificial pollination and attributes these values to the lack of pollination agent in the region.

The location of plants near the forest can also hypothetically explain the high fruiting rates from natural pollination, once abundance of bats was observed, the main pollinating agent of the species in the area. 
In the study of floral auto-incompatibility in Passiflora setacea, once buds had been bagged to selfpollinate only with the opening of the flower, it was observed, after seven days, that there was no fruit setting, concluding that wild Passiflora setacea does not promote self-pollination.

According to Bruckner et al. (2005), autoincompatibility in plants can be of two natures: gametophytic, when the phenotype of the pollen grain corresponds to its own genotype, and sporophytic, when the phenotype of the pollen grain is the same of its origin plant, where commonly, Passiflora presents it as mechanism for the determination of alogamy the incompatibility of the sporophytic type.

In determining the auto-incompatibility among flowers of the same plant (geitonogamy), after seven days of manual pollination, when removing flowers from bags, it was verified the absence of fruit in $100 \%$ of pollinated flowers.

In determining the incompatibility among plants, it was observed that after three days of pollinations, in nine of the flowers used for this study, fruit setting was observed, with fruiting rate of $34.6 \%$, showing no incompatibility between different plants. However, further studies are needed to elucidate which mechanism governs incompatibility in Passiflora setacea to better explain the different fruiting rates.

The results allow understanding that the autoincompatibility is not only a mechanism for pollination of the same flower, but that it extends to flowers of the same plant, inferring that the wild Passiflora setacea species is allogamous, requiring cross-pollination so that fruiting occurs.
The emasculation of flowers resulted in 100\% floral abortion in Passiflora setacea species. Faria and Stehmann (2010) reported that the Passiflora pohlii species when emasculated also presents floral abortion.

Fruits obtained from BRS Pérola do Cerrado cultivar presented important characteristics that are very appreciated by the consumer market (Table 5). On average, fruits with $4.9 \mathrm{~cm}$ by $4.6 \mathrm{~cm}$ in cross-sectional and longitudinal diameter were obtained, respectively. The bark hardness was $13.53 \mathrm{Kg} . \mathrm{cm}^{2}$, while mean weight observed was $55 \mathrm{~g}$. The bark thickness and the ovarian cavity diameter, in $\mathrm{mm}$, were on average, 4.04 and 37.85 respectively.

Passiflora setacea pulp had mean weight of 26.7 $\mathrm{g}$ (average yield of $48.5 \%$ ), but fruits with pulp weight of up to $37.7 \mathrm{~g}$ were observed, with mean juice volume of $15.74 \mathrm{ml}$.

The number of seeds varied strongly among samples, with 142 units between the minimum and maximum, with mean of 158 seeds and median of 163 seeds.

For soluble solids and total titratable acidity, mean values for soluble solids were $13.31^{\circ}$ Brix, with values up to $17.5^{\circ}$ Brix and average titratable acidity equal to $1.7 \mathrm{~g}$ per $100 \mathrm{~g}$ of citric acid. Viana et al. (2016) reported as a standard for frozen pulp of improved BRS Pérola do Cerrado cultivar soluble solids equal to $13,57^{\circ}$ Brix and total acidity of $2.92 \%$. Campos (2010) found soluble solids values of $13.07^{\circ}$ Brix and titratable acidity equal to $2.22 \%$, values close to those of this study for the physicochemical characteristics of Passiflora setacea fruits.

Table 1 - Climatic data of Seropédica-RJ for the study period

\begin{tabular}{ccccc}
\hline MONTH & TEMPERATURE* & RH $(\%)^{*}$ & RADIATION* & RAINFALL* \\
\hline January & 27.22 & 72.99 & 23368.84 & 88.8 \\
February & 27.58 & 66.91 & 26165.06 & 110.4 \\
March & 25.62 & 74.96 & 21285.40 & 116.6 \\
April & 23.68 & 78.41 & 14618.60 & 70.4 \\
May & 21.81 & 78.08 & 14672.72 & 71.6 \\
June & 21.38 & 76.02 & 17625.67 & 57.2 \\
July & 19.80 & 73.46 & 15759.50 & 11.8 \\
August & 20.37 & 72.00 & 14453.74 & 53.6 \\
September & 23.35 & 63.51 & 21620.75 & 16.2 \\
October & 24.58 & 69.93 & 18801.38 & 80.2 \\
November & 24.29 & 70.22 & 21012.12 & 166.2 \\
December & 25.47 & 75.76 & 18604.03 & 66.4 \\
\hline
\end{tabular}

* mean, temperature in ${ }^{\circ} \mathrm{C}$, radiation in KJ.m-2, rainfall in $\mathrm{mm}$ ) 
Table 2 - Average day length for Seropédica - RJ

\begin{tabular}{ccc}
\hline MONTH & No. FLOWERS & DAY LENGTH \\
\hline January & 12 & $1: 20 \mathrm{pm}$ \\
February & 21 & $12: 42 \mathrm{pm}$ \\
March & 20 & $11: 50 \mathrm{am}$ \\
April & 0 & $11: 14 \mathrm{am}$ \\
May & 0 & $10: 48 \mathrm{am}$ \\
June & 0 & $10: 43 \mathrm{am}$ \\
July & 0 & $10: 44 \mathrm{am}$ \\
August & 9 & $11: 36 \mathrm{am}$ \\
September & 9 & $12: 15 \mathrm{am}$ \\
October & 22 & $12: 54 \mathrm{am}$ \\
November & 33 & $1: 22 \mathrm{pm}$ \\
December & 26 & $1: 29 \mathrm{pm}$ \\
\hline
\end{tabular}

Table 3 - Measurements of floral parts

\begin{tabular}{lccc}
\hline \multicolumn{1}{c}{ MEARUREMENTS } & MEAN & MODE & STANDARD DEVIATION \\
\hline Diameter $(\mathrm{cm})$ & 7,9 & 7,5 & 0,724 \\
Petal $(\mathrm{cm})$ & 3,3 & 3,2 & 0,277 \\
Sepal $(\mathrm{cm})$ & 3,4 & 3,5 & 0,259 \\
Bracts $(\mathrm{cm})$ & 2,6 & - & 0,264 \\
Peduncle $(\mathrm{cm})$ & 7,9 & - & 1,322 \\
Pedicel $(\mathrm{cm})$ & 1,8 & 1,9 & 0,244 \\
Androgynophore $(\mathrm{cm})$ & 3,2 & 3,4 & 0,249 \\
Ovary Diameter $(\mathrm{mm})$ & 3,7 & 1,6 & 0,539 \\
Ovary Length $(\mathrm{mm})$ & 5,6 & - & 0,396 \\
Ant x Cor $(\mathrm{cm})^{*}$ & 1,7 & 1,6 & 0,241 \\
Ant x Ope $(\mathrm{cm})^{* *}$ & 2,9 & 2,9 & 0,316 \\
\hline
\end{tabular}

** Ant $\mathrm{x}$ Oper $(\mathrm{cm})$ means the distance between the axis of anthers and the operculum, in centimeters.

Table 4 - Fruiting rate of $P$. setacea for different types of pollination

\begin{tabular}{lccc}
\hline \multicolumn{1}{c}{ TYPE OF POLLINATION } & No. FLOWERS & No. FRUITS & FRUITING RATE (\%) \\
\hline Auto-pollination & 20 & 0 & 0.0 \\
Manual in the same flower & 20 & 0 & 0.0 \\
Natural/Open & 28 & 15 & 53.6 \\
Manual on different plants & 26 & 9 & 34.6 \\
\hline
\end{tabular}

Table 5 - Physicochemical characterization of Passiflora setacea fruits

\begin{tabular}{cccccc}
\hline VARIABLES & MINIMUM & MAXIMUM & MEAN & MEDIAN & $\begin{array}{c}\text { STANDADR } \\
\text { DEVIATION }\end{array}$ \\
\hline CROSS-SECTIONAL DIAMETER $(\mathrm{cm})$ & 4.9 & 5.3 & 4.9 & 4.9 & 0.229 \\
LONGITUDINAL DIAMETER $(\mathrm{cm})$ & 3.9 & 5.3 & 4.6 & 4.4 & 0.430 \\
BARK HARDNESS $\left({\left.\mathrm{kg} . \mathrm{cm}^{2}\right)}^{2}\right.$ & 10.40 & 18.60 & 13.53 & 13.2 & 2.68 \\
FRESH MASS WEIGHT (g) & 41.40 & 79.20 & 55.03 & 49.35 & 12.53 \\
BARK THICKNESS (mm) & 2.34 & 5.95 & 4.04 & 4.07 & 1.05 \\
CAVITY DIAMETER (mm) & 30.06 & 43.29 & 37.85 & 37.57 & 3.71 \\
PULP WEIGHT $(\mathrm{g})$ & 3.71 & 34.70 & 26.70 & 27.15 & 4.61 \\
JUICE VOLUME (mL) & 9.50 & 27.10 & 15.74 & 15.25 & 4.58 \\
Brix & 10.40 & 17.50 & 13.31 & 13.15 & 2.09 \\
TOTAL TITRATABE ACIDITY & 1.33 & 2.24 & 1.70 & 1.68 & 0.27 \\
NUMBER OF SEEDS & 85 & 227 & 158 & 163 & 45 \\
WEIGHT OF 100 SEEDS (g) & 1.39 & 2.08 & 1.79 & 1.85 & 0.21 \\
\hline
\end{tabular}




\section{Conclusion}

Passiflora setacea species BRS Pérola do Cerrado cultivar is responsive to climatic differences observed in the State of Rio de Janeiro, being an auto-incompatible and allogamous plant, showing absence of $100 \%$ in fruit setting and therefore requiring cross-pollination to form fruits.

Passiflora setacea species presents photoperiod of 11 hours and 30 minutes, its flowers open, at the place of this study, predominantly after 7:00 p.m.

Since Passiflora setacea flowers do not present definite curvature of styli in relation to the axis of anthers, it was not possible to classify them in TC, PC, SC.

The main effective pollination agent of this species is the bat. When flowers were manually pollinated, fruit setting rate was $34.6 \%$ and when naturally performed, fruit setting rate was $53.5 \%$.

Fruits present important physicochemical characteristics and are highly appreciated by the consumer market.

\section{References}

ATAIIDE, E.M.; de OLIVEIRA, J.C.; RUGGIERO, C. Florescimento e frutificação do maracujazeiro silvestre Passiflora setacea D. C. cultivado em Jaboticabal, SP. Revista Brasileira de Fruticultura, Jaboticabal, v.34, n.2, p.377-381, 2012.

BENEVIDES, C.R. Biologia floral e polinização de passifloraceae nativas e cultivadas na região Norte Fluminense-RJ. 2006. 88 f. Dissertação (Mestrado) - Universidade Estadual do Norte Fluminense Darcy Ribeiro, Campos dos Goytacazes, 2006.

BRUCKNER, C.H; SUASSUNA, T.M.F; RÊGO, M.M; NUNES, E.S. Auto-incompatibilidade do maracujá implicações no melhoramento genético. In: FALEIRO, F. G.; JUNQUEIRA, N.T.V.; BRAGA, M.F. Maracujá: germoplasma e melhoramento genético. Planaltina: Embrapa Cerrados, 2005. p.81-106.

CAMPOS, A. V. S. Características físico-químicas e composição mineral da polpa de Passiflora setacea. 2010. 90 f. Dissertação (Mestrado) - Universidade de Brasília, Brasília, DF, 2010.

CERVI, A.C. Passifloracea do Brasil. Estudo do gênero Passiflora L., subgênero Passiflora. Madrid: Fontqueria, 1997. p.92.
EMBRAPA. Lançamento da cultivar de maracujazeiro Silvestre BRS Pérola do Cerrado. Brasília, DF: Embrapa Cerrados, 2018. Disponível em: $\leq$ http://www.cpac. embrapa.br/lancamentoperola/>. Acesso em: 22 maio 2018.

ENDRESS, P.K. Origins of flower morphology. Journal of Experimental Zoology Part A: Ecological Genetics and Physiology, Hoboke, v.291, n.2, p.105-115, 2001.

FALEIRO, F.G.; JUNQUEIRA, N.T.V.; JESUS, O.N.; COSTA, A.M.; MACHADO, C.F.; JUNQUEIRA, K.P.; ARAÚJO, F.P.; JUNGHANS, T.G. Espécies de maracujazeiro no mercado internacional. JUNGHANS, T.G.; JESUS, O.N. (Ed.). Maracujá: do cultivo à comercialização. Brasília, DF: Embrapa, 2017. p.15-37.

FALEIRO, F.G; JUNQUEIRA, N.T.V; BRAGA, M.F. Maracujá: germoplasma e melhoramento genético. Planaltina: Embrapa Cerrados, 2005. p.670.

FARIA, F.S; STEHMANN, J.R. Biologia reprodutiva de Passiflora capsularis L. e P. pohlii Mast. (Decaloba, Passifloraceae). Acta Botânica Brasileira, Belo Horizonte, v.24, n.1 p.262-269, 2010.

GONÇALVES, E.G; LORENZI, H. Morfologia vegetal, organografia e dicionário ilustrado de morfologia das plantas vasculares. 2.ed. São Paulo: Instituto Plantarum de Estudo da Flora, 2011. 444p.

GUIMARÃES, T.G; DIANESE, A.C; OLIVEIRA, C.M; MADALENA, J.O.M; FALEIRO, F.G; JUNQUEIRA, N.T.V; LIMA, H.C; CAMPOS, G.A. Recomendações técnicas para o cultivo de Passiflora setacea cv. BRS Pérola do Cerrado. Planaltina: Embrapa, 2013. 7p. (Comunicado Técnico, 174)

JUNGHANS, T.G; JESUS, O.N; JUNQUEIRA, N.T.V, FALEIROS, F.G. Passiflora setacea DC. In: JUNGHANS, T.G. Guia de plantas e propágulos de maracujazeiro. Brasília, DF: EMBRAPA, 2015. p.75-82.

JUNQUEIRA, N.T.V.; BRAGA, M.F.; FALEIRO, F.G.; PEIXOTO, J.R.; BERNACCI, L.C. Potencial de espécies silvestres de maracujazeiro como fonte de resistência a doenças. In: FALEIRO, F.G.; JUNQUEIRA, N.T.V.; BRAGA, M.F. Maracujá: germoplasma e melhoramento genético. Planaltina: Embrapa Cerrados, 2005. p. 81-106. 
RIBEIRO, D.P. Biologia reprodutiva e compostos bioativos dos frutos de Passiflora setacea D.C. 2014. 68 f. Dissertação (Mestrado) - Universidade Estadual do Sudoeste da Bahia, Vitória da Conquista, 2014.

ROCHA, D.I. Estudo dos caracteres florais associados à ornitofilia e quiropterofilia em espécies de Passiflora (Passifloraceae). 2015. 148 f. Dissertação (Mestrado) Universidade Estadual de Campinas, Campinas, 2015.

RUGGIERO, C. Alguns fatores que podem influir na frutificação. In: RUGGIERO, C. (Ed.). Cultura do maracujazeiro. Ribeirão Preto: Editora Legis Summa, 1987. p.76-85.
TAKHTAJAN, A.L. Outline of the classification of flowering plants (magnoliophyta). The Botanical Review, Bronx, v.46, p.226-359, 1980.

VASCONCELLOS, M.A.S. Biologia floral do maracujá doce (Passiflora alata Dryand) nas condições de Botucatu - SP. 1991. 99 f. Dissertação (Mestrado em Agronomia) - Faculdade de Ciências Agronômicas, Universidade Estadual Paulista, Botucatu, 1991.

VIANA, M.L; COSTA, A.M; CELESTINO, S.M. Informações para a composição de tabela nutricional da polpa do maracujá BRS Pérola do Cerrado. Planaltina, DF: Embrapa Cerrados, 2016. 